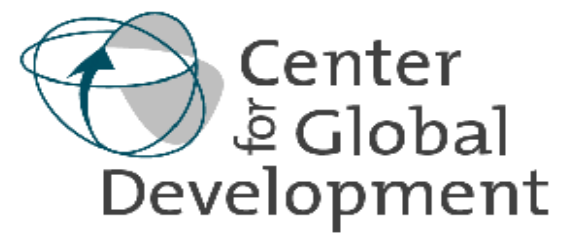

Working Paper Number 59

May 2005

\title{
Domestic Financial Regulations in Developing Countries: Can they Effectively Limit the Impact of Capital Account Volatility? By Liliana Rojas-Suarez
}

Abstract
This paper identifies two alternative forms of prudential regulation. The first set is
formed by regulations that directly control financial aggregates, such as liquidity
expansion and credit growth. An example is capital requirements as currently
incorporated in internationally accepted standards, namely, capital requirements with
risk categories used in industrial countries. The second set, which can be identified
as the "pricing-risk-right" approach, works by providing incentives to financial
institutions to avoid excessive risk-taking activities. A key feature of this set of
regulations is that they encourage financial institutions to internalize the costs
associated with the particular risks of the environment where they operate.
Regulations in this category include ex-ante risk-based provisioning rules and capital
requirements that take into account the risk features particular to developing
countries. This category also includes incentives for enhancing market discipline as a
way to differentiate risk-taking behavior between financial institutions
The main finding of the paper is that the first set of regulations-the most commonly
used in developing economies-have had very limited usefulness in helping countries
to contain the risks involved with more liberalized financial systems. The main reason
for this disappointing result is that, by not taking into account the particular
characteristics of financial markets in developing countries, these regulations cannot
effectively control excessive risk-taking by financial institutions. Moreover, the paper
shows that, contrary to policy intentions, this set of prudential regulations can
exacerbate rather than decrease financial sector fragility, especially in episodes of
sudden reversal of capital flows.
In contrast, the second set of prudential regulations can go a long way in helping
developing countries achieve their goals. The paper advances suggestions for how to
sequence the implementation of these regulations for different groups of countries.

The Center for Global Development is an independent, nonprofit policy research organization that is dedicated to reducing global poverty and inequality and to making globalization work for the poor.

Use and dissemination of this Working Paper is encouraged; however, reproduced copies may not be used for commercial purposes. Further usage is permitted under the terms of the Creative Commons License. The views expressed in this paper are those of the author and should not be attributed to the board of directors or funders of the Center for Global Development.

www.cgdev.org 


\title{
Domestic Financial Regulations in Developing Countries: Can they Effectively Limit the Impact of Capital Account Volatility? ${ }^{1}$
}

\author{
Liliana Rojas-Suarez \\ Center for Global Development
}

\section{Introduction}

After more than a decade of financial sector liberalization, both of domestic markets and of international financial transactions (capital account liberalization), policymakers in many developing countries remain concerned about the effects that large and highly volatile capital flows have on their financial systems. This is not surprising given the increasing evidence that, in sharp contrast to policy objectives, financial crises have become more frequent following financial liberalization. However, in spite of the tremendous costs associated with the resolution of crises and signs of discontent among the population with the outcome of some reforms, to date there is no significant evidence indicating a reversal of the reform process. With few exceptions (mostly of temporary nature) developing countries have not gone back to the era of highly controlled domestic financial markets or closed capital accounts. While one could advance a number of hypotheses explaining this “commitment to reforms”, developing countries' decisions and actions seem to indicate that policymakers perceive capital inflows as a necessary component to achieve growth and development. Rather than severely restricting the movement of capital, many countries have intensified their attempts to strengthen their domestic economies, and especially their financial systems. The hope is that if only the right policies could be designed to insulate domestic financial sectors from the volatility of international capital flows, countries could enjoy the benefits of both additional foreign capital for growth and stable domestic financial systems.

In this regard, policy recommendations for dealing with the domestic financial market problems generated by highly volatile capital flows have not been in short supply, and many of these recommendations have indeed been applied in a wide range of developing countries. While the policy menu is quite ample, analysts' emphasis on one set of recommendations rather than another greatly depends on what they view as the major cause of the problem. For those that believe that capital flow volatility is largely the result of a faulty international financial architecture that does not sufficiently take into account market imperfections and information asymmetries at the international level, appropriate policies include further official intervention, such as additional controls on the activities of the international capital markets, including regulation of hedge funds. For this group of analysts, capital controls are a desirable policy response by developing countries.

To others, the major cause of capital flow volatility experienced by developing countries resides in the domestic macroeconomic policies of the recipient countries. To this group, policy

\footnotetext{
${ }^{1}$ I would like to thank valuable comments from José Antonio Ocampo and other members of the Capital Markets Liberalization Task Force organized by Joseph Stiglitz's Initiative for Policy Dialogue, and Trond Augdal and Sebastian Sotelo for excellent research assistant support. The errors that remain are, of course, my own.
} 
recommendations stress the avoidance of fiscal, monetary and external imbalances and the maintenance of a sustainable debt path. Yet, there is third group of analysts that view domestic financial weaknesses as the key cause of major disruptions derived from capital flow volatility. Since a large proportion of capital inflows are intermediated through domestic financial markets, and especially banks in developing countries, the central policy prescription for this group of analysts lies in strengthening domestic financial institutions through improved regulation and supervision. An additional policy recommendation deals with increasing the maturity of financial assets by encouraging the development of domestic capital markets.

Emphasis on one set of policy prescriptions does not mean, of course, total disregard of the others. Indeed, most analysts would agree that the disruptive effects of capital flow volatility on developing countries is the result of a combination of most of the factors mentioned above. For example, those that emphasize improvements in the regulatory and supervisory framework of developing countries, also recognize that these policy tools can only be effective in a stable macroeconomic environment, and some analysts in this group would also support certain forms of capital controls.

In this connection, this paper focuses on a particular aspect of the problem at hand and asks how appropriate prudential financial regulation should be designed to contain the risks resulting from liberalized financial systems facing high external capital volatility. The view taken here is that in order to provide advice to developing countries on how to improve regulation and supervision of financial markets, it is first necessary to answer two questions. The first is whether commonly used regulatory tools have been effective in reducing the adverse effects of capital flow volatility on domestic financial markets. The second is whether appropriate regulatory and supervisory tools in developing countries need to be different from those that work in industrial countries and even differ between developing countries at different degrees of financial sector development.

To conduct this task, the paper identifies two alternative forms of prudential regulation. The first set is formed by regulations that directly control financial aggregates, such as liquidity expansion and credit growth. An example is capital requirements as currently incorporated in internationally accepted standards; namely capital requirements with risk categories used in industrial countries. The second set, which can be identified as the "pricing-risk-right" approach, works by providing incentives to financial institutions to avoid excessive risk-taking activities. A key feature of this set of regulations is that they encourage financial institutions to internalize the costs associated with the particular risks of the environment where they operate. Regulations in this category include ex-ante risk-based provisioning rules and capital requirements that take into account the risk features particular to developing countries. This category also includes incentives for enhancing market discipline as a way to differentiate risk-taking behavior between financial institutions.

The main finding of the paper is that the first set of regulations - the most commonly used in developing economies-- have had very limited usefulness in helping countries to contain the risks involved with more liberalized financial systems. The main reason for this disappointing result is that, by not taking into account the particular characteristics of financial markets in developing countries, these regulations cannot effectively control excessive risk 
taking by financial institutions. Moreover, the paper shows that, contrary to policy intentions, this set of prudential regulations can exacerbate rather than decrease financial sector fragility, especially in episodes of sudden reversal of capital flows.

In contrast, the paper claims, the second set of prudential regulation can go a long way in helping developing countries achieving their goals. The paper advances suggestions for the sequencing of implementation of these regulations for different groups of countries.

The rest of this paper is organized as follows. Section II summarizes features of domestic financial markets in developing countries that exacerbate the effects of international capital flow volatility on the domestic economies. Section III assesses the experience of developing countries with the most commonly used prudential regulatory and supervisory tools for coping with the volatility of capital flows and advances explanations for why these policies have been of very limited usefulness. Section IV advances specific policy recommendations for prudential regulatory policies that might have a good chance of working effectively in developing countries. In doing so, the section identifies and analyzes features of prudential regulation used in industrial countries that would need to be modified to be effective in developing countries. Section $\mathrm{V}$ concludes the paper.

\section{Features of Financial Markets in Developing Countries that Exacerbate the Adverse Effects of Capital Flow Volatility}

Sudden stops of capital inflows are a most feared characteristic of capital account volatility in developing countries as they cause an abrupt and dramatic reduction in sources of funding for growth and development. A drastic decrease in net capital inflows will bring about pressures on a number of financial variables. By reflecting a reduction in the overall demand for domestic assets, interest rates will increase and prices of assets--held either by locals or foreigners-will decrease. Pressures on the exchange rate and/or international reserves will also materialize.

The extent to which domestic financial systems in developing countries can manage the adverse impact of a sudden reversal of capital inflows is certainly influenced by the strength of the systems before the shock ${ }^{2}$. For example, the damage to the value of banks' assets as a result of a sudden increase in interest rates will be minimized if the quality of their loan portfolio is high. This would imply that the banks' client base is able to generate liquidity to service its payments on a timely basis and that the ratio of non-performing loans to loans is low before the emergence of the shock. Likewise, the effect of a significant exchange rate depreciation on the quality of banks' balance sheets would be minimized if bank managers had either arranged adequate hedges on net foreign-currency denominated bank liabilities or strictly limited these exposures in countries lacking liquid private sector markets to hedge foreign exchange positions. $^{34}$ The stronger the initial conditions of banks before the shock, the greater the

\footnotetext{
${ }^{2}$ As discussed in the introduction, there are also a number of other factors that will determine the impact of the shock on the domestic economy.

${ }^{3}$ In many developing countries, banks' risks from net foreign-currency exposures go beyond the currency

denomination of their assets and liabilities. Potential exchange rate risks also arise from lending in foreign currency
} 
confidence of depositors in the banks' capacity to weather the shock and, therefore, the lower the probability that depositors will run the banks when adverse international financial conditions arise.

Indeed, strong confidence in domestic financial systems is usually reflected in a: (a) high degree of financial intermediation; (b) stable deposit base and (c) dynamic financial system that intermediates funds to the private sector on a sound basis.

These features of financial sector strength were not typical characteristics of developing countries in the 1980s. At the time, in most developing countries, depository institutions - banks and savings institutions issuing deposit-like liabilities - were the most important vehicles for institutional savings. However, with the exception of a few countries, in the 1980s deposit liabilities to the private sector of all banking institutions constituted a low percentage of GDP in developing countries relative to the corresponding ratio in major industrial countries. In other words, relatively few saving funds were held in financial intermediaries.

Not only the banking sectors were relatively shallow, but also the liabilities and assets of these institutions were of short maturity: bank deposits financed short-term loans, short-term government paper and central bank securities. The combination of these two features reflected lack of depositors' confidence in domestic financial systems and made these systems highly vulnerable to capital flow volatility.

Recognition of the need to strengthen domestic financial systems led to comprehensive reforms in a number of developing countries during the late 1980s and 1990s. By attempting to improve the quality of financial intermediaries' portfolios, the policy objective was to improve investors' confidence in the financial systems and, therefore, to increase the resilience of domestic financial systems to capital flow volatility. Moreover, it was also expected that stronger financial systems would contribute to lower the volatility of capital flows.

While it is difficult to argue against the advantages of stronger financial systems as a tool to help mitigate the adverse impact of capital flow volatility, efficient and effective implementation of reforms requires careful consideration of the appropriate pace, timing and sequencing of these reforms. After all, even in a number of industrial countries, financial liberalization occurred only in the 1970s and in some countries like Norway in the early 1980s. A reform implemented in countries with the lowest level of financial development would most likely have a different effect than in counties with more developed financial systems.

to firms and individuals with revenues denominated in domestic currency. As will be discussed below, incentives for banks to adequately avoid excessive foreign-exchange risk taking depends on the announced government policies. ${ }^{4}$ The importance for banks to limit their net foreign-currency liabilities cannot be overstressed. In most developing countries, forward markets for foreign exchange are lacking. Moreover, in the few cases where these markets exist, they do not have sufficient depth and liquidity as to provide adequate hedge in times of high exchange rate volatility. For example, in late 1998 in Brazil, when expectations about exchange rate depreciation mounted, the only source of hedge came from the government who placed a large number of U.S. dollar-denominated government securities in banks' balance sheets. While this action insulated the banking system from the sharp devaluation in early 1999, it also transferred the exchange rate risk (and the associated fiscal costs) from the private sector to the government. 
The issue of reform-readiness, however, was not sufficiently taken into account in developing countries. Indeed, one can identify "clusters" of reforms over the last two decades that have been implemented in countries with very different degrees of development. The first "cluster" included both liberalization of interest rates and dismantling of credit controls. These reforms proved to be destabilizing in the absence of appropriate supervision ${ }^{5}$. Indeed, this "first round" of reforms created incentives for increased risk-taking by banks. Competition for market share without appropriate "rules of the game" determining not only "entry" requirements into the banking systems, but also provisions for "exit" out of the system resulted in dramatic increases in the risk features of banks' portfolios that were fully exposed following the eruption of adverse shocks. The second "cluster", therefore, focused on improving the regulatory and supervisory frameworks-including advances in the implementation of the recommendations of the Basel Committee $^{6}$. Once again, however, these improvements were not sufficient to prevent the eruption of large financial crises that followed the reversal of capital inflows that started in the late 1990s and continued through 2002. Reasons for the less-than-satisfactory results of these reforms efforts will be discussed in the next sections.

While, generally speaking, developing countries around the world have followed similar “clusters" of reforms, not all regions, or countries within a region, have implemented reforms at the same time or with the same intensity. Chart 1 reproduces Abiat and Mody's (2003) index of financial liberalization by region. ${ }^{7}$ The most important result is that, in spite of partial reversal in some regions at some times, there is a clear trend towards increased financial liberalization. Among regions of the developing world, East Asia has the most liberalized financial systems and South Asia has the least liberalized systems. An interesting finding is that because of continuous progress in liberalization by OECD countries, the "financial liberalization gap" between developing and industrial countries has not decreased significantly over time, with the exception of Latin America from the mid-1980s to the mid-1990's, when the region undertook massive reforms and consequently reduced the financial liberalization gap with industrial countries.

\footnotetext{
${ }^{5}$ See, Diaz Alejandro (1985) for a recount of how financial liberalization without appropriate supervision resulted in severe financial crises in Latin America in the early 1980s.

${ }^{6}$ In a recent database constructed by Barth, Caprio and Levine (2001), only 17 countries out of 110 surveyed responded that their minimum required capital-to-asset ratio did not conform to the Basel's guidelines.

${ }^{7}$ The index is formed by six components: (a) credit controls; (b) interest rate controls; (c) entry barriers, including limits on the participation of foreign banks; (d) privatization of the financial sector and (e) restrictions on international financial transactions. The higher the value of the index, the higher the degree of financial liberalization. See Abiat and Mody (2003) for a detailed methodology.
} 


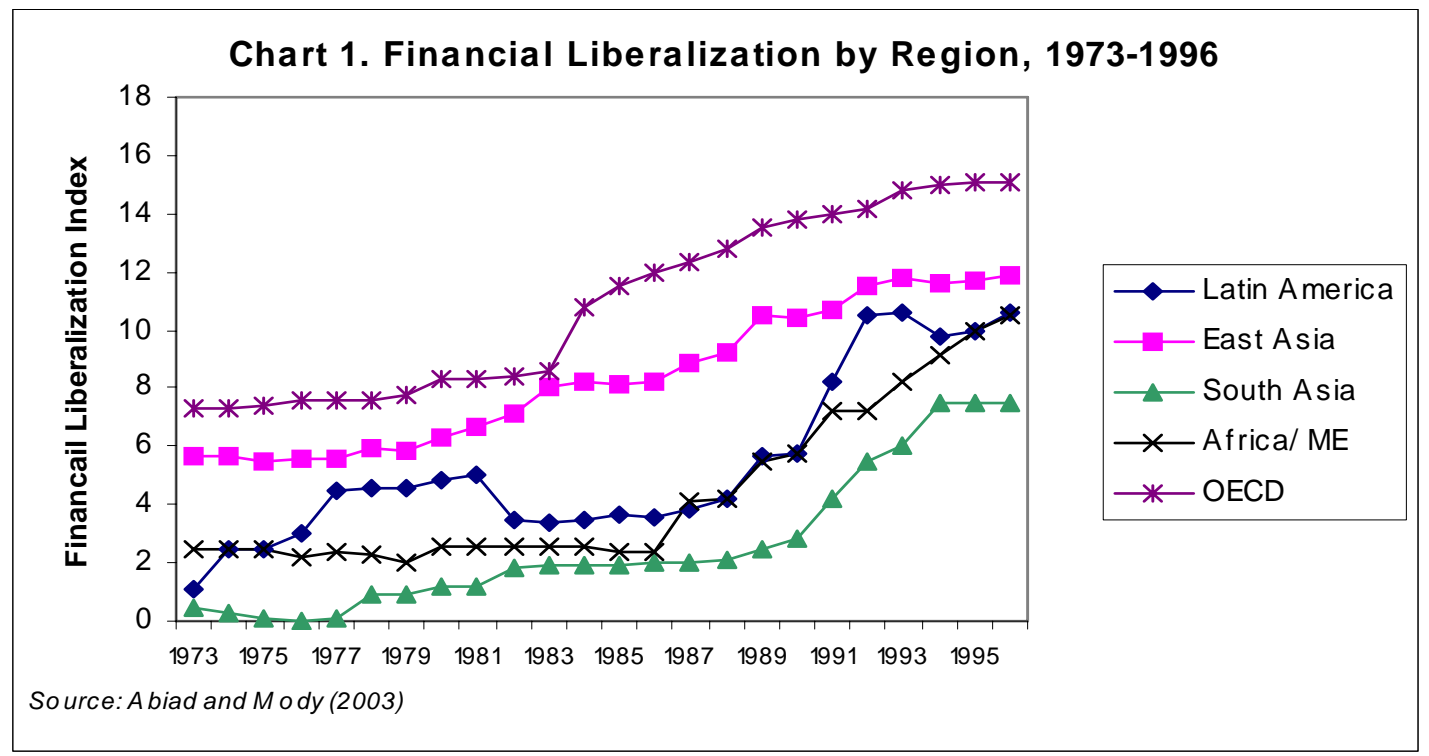

In addition to financial liberalization and improvements in regulatory and supervisory frameworks, developing countries have made significant efforts to attract foreign capital into their financial systems. In many cases, this was the result of deep banking crises that required huge injections of capital in order to restore financial solvency. In other cases, the increased participation of foreign banks in developing countries was the result of a combination of lower yields on investments in industrial countries and the expectations of higher yields on investments in developing countries as a result of the impetus from the structural reforms of the 1990s. ${ }^{8}$ The trend toward internationalization of banking systems have been particularly notorious in Latin America, where in some countries, such as Mexico, the effective foreign control in banking systems (measured as the ratio of loans to total loans in the banking system provided by banks that have at least 40 percent foreign ownership in local institutions) reached more than $70 \%$ in 2002 . This compares with a percentage of just over 10 percent in 1996 (see Chart 2).

\footnotetext{
${ }^{8}$ For an analysis of the role of foreign banks in Latin America, see Latin American Shadow Financial Regulatory Committee (2002).
} 
After two decades of reforms, have the main weaknesses that characterized developing countries financial markets in the early 1980s improved? Has the depth of financial intermediation increased during the late 1990s and early 2000s? Are there signals that investors'

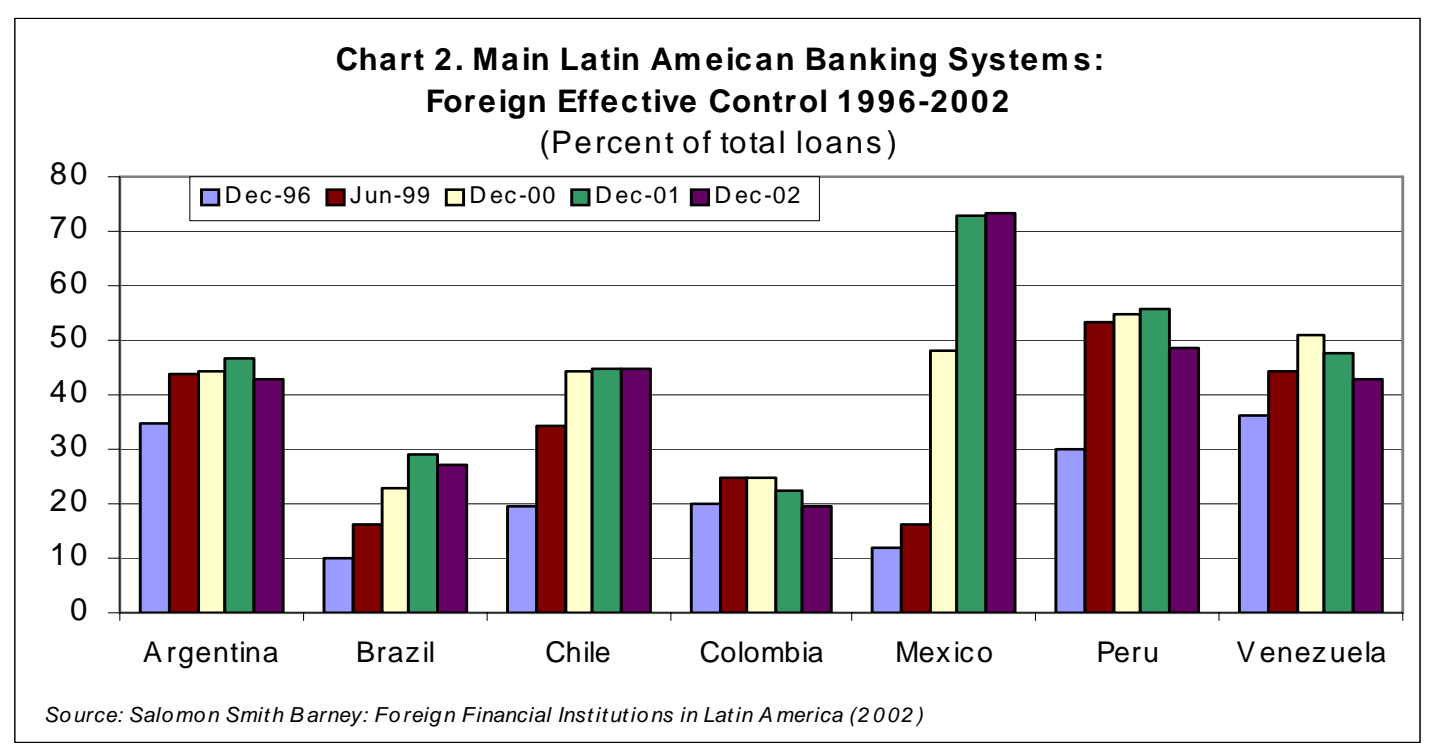

confidence in the strength of domestic financial systems has improved? An analysis of the data provides a mixed response. Consider first, the degree of financial deepening. Table 1 shows that for most countries (with countries in East Asia as an important exception) the depth of financial intermediation, measured by the ratio of deposits to GDP, has remained below 30 percent $^{9}$. This contrasts with industrial countries where the ratio is above 50 percent in most cases.

The relative shallowness of financial systems in developing countries suggests that investors' confidence that financial assets will yield a positive and stable rate of return over an extended period of time has remained weak. Investors' concerns are reflected in the high degree of volatility in the ratio of deposits to GDP that persisted in developing countries during the 1990s. This is shown in the last two columns of Table 1 that presents the coefficient of variation during the 1980s and the 1990s-early 2000s. Most developing countries not only displayed a much higher degree of volatility of deposits to GDP than did industrial countries, but volatility actually increased from the first to the second period in a number of developing countries.

The persistence of investors' concerns finds justification in Table 2, which presents real interest rates on deposits in selected industrial and developing countries over the last two decades. In contrast to the industrial countries, where real interest rates have remained mostly positive, at low levels, and quite stable (as measured by the values of the standard deviation), in developing countries real interest rates remained either negative for substantial periods of time or skyrocketed to unsustainably high levels. Times of extremely high real interest rates by no means indicated high levels of productivity. Instead, they reflected the elevated risk of liabilities issued by domestic borrowers as investors perceived a high probability of significant losses in the real value of their assets either through inflation, devaluation, controls or outright default. With the

\footnotetext{
${ }^{9}$ In some cases, most notably Venezuela, this ratio has declined significantly.
} 
exception of East Asian countries, interest rate volatility in developing countries has been much higher than in industrial countries and, in many countries, has even increased during the 1990searly 2000 s relatively to the 1980 s.

\section{Table 1. Bank Deposits to GDP in Selected Countries}

\begin{tabular}{|c|c|c|c|c|c|}
\hline \multirow{3}{*}{$\begin{array}{c}\text { Country } \\
\text { Industrial Countries }\end{array}$} & \multicolumn{3}{|c|}{ Ratio } & \multicolumn{2}{|c|}{ Coefficient of Variation } \\
\hline & $1980-89$ & 1990-2003* & $2003^{\star}$ & $1980-89$ & $1990-2003^{*}$ \\
\hline & & & & & \\
\hline Australia & 38.13 & 59.11 & 69.01 & 0.11 & 0.10 \\
\hline Canada & 64.28 & 73.93 & 75.25 & 0.04 & 0.03 \\
\hline France & 64.72 & 62.99 & 70.77 & 0.03 & 0.08 \\
\hline Norway & 47.95 & 51.84 & 53.35 & 0.10 & 0.06 \\
\hline Sweden & 48.91 & 39.65 & 37.39 & 0.05 & 0.04 \\
\hline United States & 61.02 & 56.84 & 60.37 & 0.04 & 0.07 \\
\hline Africa and Middle East & & & & & \\
\hline Gabon & 15.06 & 12.31 & 13.12 & 0.13 & 0.15 \\
\hline Ghana & 7.20 & 13.58 & 16.82 & 0.25 & 0.19 \\
\hline Niger & 10.61 & 8.28 & 6.99 & 0.23 & 0.39 \\
\hline Nigeria & 20.48 & 15.03 & 21.38 & 0.18 & 0.25 \\
\hline South Africa & 51.21 & 48.20 & 61.48 & 0.03 & 0.31 \\
\hline Uganda & 5.74 & 9.15 & 14.75 & 0.32 & 0.38 \\
\hline Turkey & 24.99 & 35.56 & 41.16 & 0.05 & 0.32 \\
\hline Asia & & & & & \\
\hline Indonesia & 17.91 & 45.93 & 49.80 & 0.31 & 0.16 \\
\hline Korea & 32.10 & 51.31 & 78.92 & 0.08 & 0.35 \\
\hline Malaysia & 90.63 & 105.57 & 123.44 & 0.29 & 0.23 \\
\hline Thailand & 51.57 & 91.18 & 102.12 & 0.22 & 0.17 \\
\hline Latin America & & & & & \\
\hline Argentina & 18.74 & 18.77 & 23.05 & 0.21 & 0.35 \\
\hline Brazil & 29.05 & 34.30 & 27.23 & 0.45 & 0.45 \\
\hline Chile & 27.49 & 35.63 & 35.61 & 0.09 & 0.09 \\
\hline Colombia & 26.29 & 27.21 & 26.60 & 0.06 & 0.13 \\
\hline Mexico & 22.33 & 25.87 & 24.97 & 0.31 & 0.14 \\
\hline Peru & 17.47 & 21.06 & 25.42 & 0.17 & 0.25 \\
\hline Venezuela, Rep. Bol. & 50.10 & 24.23 & 14.08 & 0.18 & 0.39 \\
\hline Transition Economies & & & & & \\
\hline Bulgaria & n.a. & 40.34 & 31.41 & n.a. & 0.58 \\
\hline Kazakhstan & n.a. & 10.14 & 15.34 & n.a. & 0.51 \\
\hline Poland & 37.90 & 31.29 & 37.25 & 0.24 & 0.15 \\
\hline Romania & 25.48 & 25.09 & 21.36 & 0.10 & 0.42 \\
\hline Russia & n.a. & 16.07 & 20.95 & n.a. & 0.15 \\
\hline Ukraine & n.a. & 15.54 & 23.24 & n.a. & 0.65 \\
\hline
\end{tabular}




\section{Table 2. Real Interest Rates in Selected Countries}

\begin{tabular}{|c|c|c|c|c|c|}
\hline \multirow{3}{*}{ Industrial Countries } & & \multicolumn{2}{|c|}{ Standard Deviation } \\
\hline & \multicolumn{2}{|r|}{$\begin{array}{c}\text { Ratio } \\
1990-2003\end{array}$} & $2003^{*}$ & \multirow[t]{2}{*}{$1980-89$} & \multirow[t]{2}{*}{$1990-2003^{\star}$} \\
\hline & & & & & \\
\hline Germany & 2.58 & 2.29 & 1.28 & 0.76 & 1.40 \\
\hline Japan & 0.69 & 0.53 & 0.30 & 1.32 & 0.74 \\
\hline Sweden & 2.38 & 1.75 & 1.18 & 2.37 & 2.00 \\
\hline United Kingdom & 3.16 & 1.96 & 1.07 & 3.34 & 1.48 \\
\hline United States & 4.34 & 1.87 & -1.12 & 1.97 & 1.50 \\
\hline \multicolumn{6}{|l|}{ Middle East } \\
\hline Algeria & -5.23 & -4.97 & 2.67 & 3.26 & 10.35 \\
\hline Egypt & -6.67 & 2.10 & 3.98 & 4.31 & 4.99 \\
\hline Israel & -15.99 & 2.34 & 5.93 & 56.71 & 3.79 \\
\hline Turkey & -10.91 & -1.13 & 12.38 & 34.19 & 10.91 \\
\hline \multicolumn{6}{|l|}{ Africa } \\
\hline Central African Rep. & 3.79 & 2.30 & 1.87 & 7.46 & 8.08 \\
\hline Gabon & 1.31 & 2.89 & 4.50 & 7.29 & 12.35 \\
\hline Malawi & -5.92 & 6.23 & 25.43 & 7.60 & 16.16 \\
\hline Sierra Leone & -50.28 & -14.44 & 0.82 & 46.83 & 24.02 \\
\hline South Africa & -1.89 & 4.23 & 3.90 & 5.35 & 2.72 \\
\hline \multicolumn{6}{|l|}{ South Asia } \\
\hline Bangladesh & 4.22 & 3.62 & 2.16 & 1.94 & 3.10 \\
\hline Sri Lanka & 3.03 & 1.07 & -0.31 & 6.86 & 2.72 \\
\hline \multicolumn{6}{|l|}{ East Asia } \\
\hline Malaysia & 3.34 & 2.62 & 2.01 & 2.93 & 1.09 \\
\hline Philippines & -0.34 & 2.64 & 2.23 & 10.35 & 1.86 \\
\hline Singapore & 3.04 & 1.21 & 0.00 & 1.73 & 1.27 \\
\hline Thailand & 5.66 & 3.81 & -0.48 & 5.82 & 2.34 \\
\hline \multicolumn{6}{|l|}{ Latin America } \\
\hline Argentina & -40.30 & -15.78 & 6.56 & 42.69 & 75.44 \\
\hline Chile & 8.87 & 4.91 & -0.08 & 12.41 & 3.76 \\
\hline Colombia & 7.32 & 13.13 & 5.82 & 4.53 & 5.63 \\
\hline Ecuador & -13.57 & -0.59 & 3.26 & 16.10 & 28.64 \\
\hline Mexico & -16.79 & -0.18 & -1.46 & 22.46 & 4.68 \\
\hline Venezuela & -9.12 & 5.81 & -2.59 & 13.85 & 22.61 \\
\hline \multicolumn{6}{|l|}{ Transition Countries } \\
\hline Bulgaria & n.a. & -118.01 & 0.74 & n.a. & 279.86 \\
\hline Czech Republic & n.a. & -0.90 & 1.23 & n.a. & 1.73 \\
\hline Poland & -144.55 & -36.86 & 2.99 & 261.04 & 137.46 \\
\hline Russia & n.a. & -24.42 & -9.19 & n.a. & 35.00 \\
\hline
\end{tabular}


An indicator of financial strength that is rarely analyzed is the share of government claims in bank assets. This indicator, however, is quite important because, after all, one of the objectives of financial liberalization and reforms was to reduce the massive transfer of resources from the private financial sector to the public sector, which in the 1970s and early 1980s had served to finance large fiscal deficits. Yet, in a number of cases, the results have been disappointing. While governments significantly reduced their interference in direct allocation of credit, a number of governments continued financing their deficits with resources from the domestic banking system. Whereas in the 1980s this was achieved by direct lending to governments or high reserve requirements, since the mid-1990s governments issued large amounts of debt that was purchased by banks and by the general public. Indeed, it is interesting to note that in addition to bank deposits, government paper constitutes the other major source of liquidity in developing countries. Absent liquid private capital markets, with some noteworthy exceptions including Chile and some Asian countries, investors in developing countries largely hold their financial wealth in bank deposits and government paper. As will be discussed in the next section, this development has had important consequences for the effectiveness of reserve requirements.

Chart 3 illustrates the evolution of government paper held by domestic banking systems in developing countries. The chart shows that the share of government paper in banks' balance sheets increased from the 1980-94 period to the 1995-2003 period in many

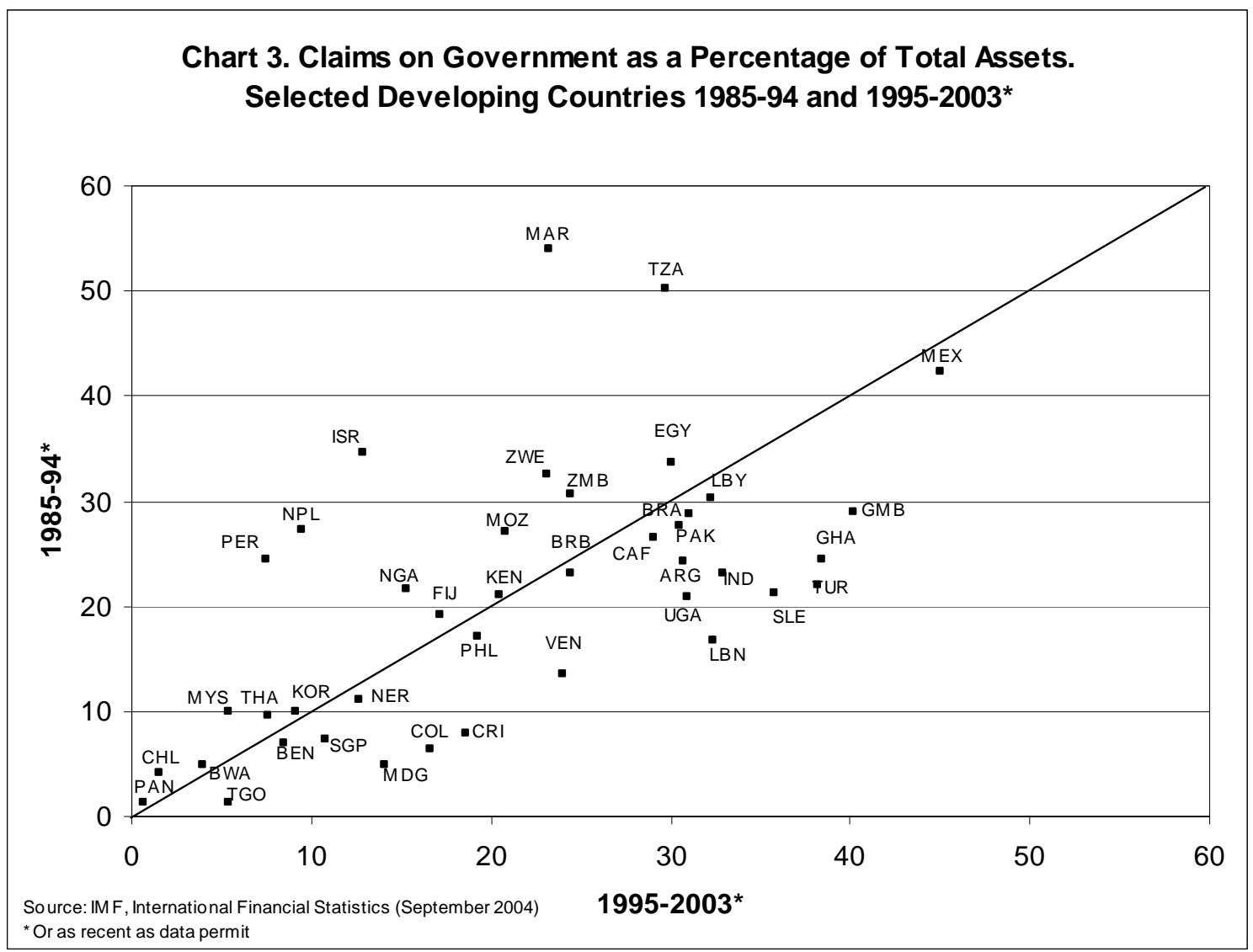


developing countries (many countries are located to the right of the 45 degree line). This result is a sad irony: a significant component of the efforts of financial sector reform undertaken in the early to mid-1990s aimed at decreasing the share of banks' claims on government! It is important to note, of course, that the results in Chart 3 should not be entirely attributed to an inappropriate implementation of regulatory reform. In a number of countries, banking crises were resolved by replacing bad loans with government paper (Mexico and the post 1997- East Asian-crisis countries are examples of this). Given the lack of access of emerging markets to international capital markets during crisis periods, it is very difficult to conceive alternative procedures for banking crisis resolution. To take this into account, banking crisis periods were eliminated from the sample, including five years after the crisis. The basic result did not change: many banking systems in developing countries held as much or more government paper in the most recent period relative to the 1980 s. $^{10}$

As Chart 3 shows, the ratio of claims on government as a percentage of deposits not only has increased for many countries, but is also very high. Large countries such as Argentina, Brazil, Mexico, and Turkey display ratios above 30 percent. Among the sample of countries, those that can be identified as succeeding in reducing this ratio to a low level include Chile, Panama, Botswana, Malaysia and Thailand.

These large and increasing stocks of government paper in the balance sheet of developing country financial systems have exacerbated the adverse effects of sudden stops of capital flows into the domestic economies, as demonstrated by the recent crisis experience in Argentina. As sudden stops usually bring about a decline in the market value of government debt, banks' asset value deteriorates. Thus, a significant deterioration in the credit risk perception of sovereigns by international investors may translate into severe problems in domestic banking systems.

In sum, financial systems characterized by a large predominance of short-term and highly volatile instruments are features of most developing countries that contribute to exacerbate the adverse effects of capital flow volatility on the stability of domestic systems. These features also constrain the effectiveness of policy instruments to deal with a sudden reversal of capital flows ${ }^{11}$. The evidence suggests that the reforms undertaken since the 1980s have not been able to substantially improve the destabilizing features of financial systems in most developing countries. The next section will assess two of the most common prudential regulatory policies implemented to deal with capital flow volatility.

\footnotetext{
${ }^{10}$ The case of Argentina is particularly telling. During the early 1990s, following the implementation of the currency board, banks decreased their relative holding of government paper. After the banking crisis of 1995, there was an increase in holdings of government paper that one can associate with the restructuring efforts of the financial sector, including improving the liquidity of the banks. However, for a long time after the crisis was completely resolved, banks continued to increase their claims on government. By the end of 2000 the share of bank claims on central and non-central government as a percentage of total assets reached 25 percent, a ratio close to the 27 percent observed in 1991 at the beginning of the currency board.

${ }^{11}$ Consider, for example, that following a sudden reversal of capital inflows policy makers decide to increase the short-term policy rate in order to stabilize exchange rate movements. Because of the absence of a yield curve covering a large spectrum of maturities, the increase in the policy rate would bring about an increase in interest rates throughout the financial sector, imposing unwanted effects on the entire system.
} 


\section{Commonly Used Financial Regulatory Policies to Deal with the Adverse Effects of Capital Flow Volatility}

While experience shows that recent reforms have not resulted in the desired increase in financial deepening in most developing countries, the question remains as to whether some forms of regulations may be more effective than others in dealing with the adverse effects of capital flow volatility on the, currently shallow, domestic financial markets.

Prudential regulatory policies to deal with capital flow volatility can be divided into two groups. ${ }^{12}$ The first consists of regulations aimed at directly controlling financial aggregates, such as liquidity expansion and credit growth. Their purpose is to limit the expansion of balance sheets following a period of large capital inflows to minimize the adverse effects on the financial system if a sudden reversal of the inflows were to materialize. The best-known examples are the use of reserve requirements and capital requirements as currently incorporated in international standards, namely capital requirements that contain risk categories used in industrial countries. ${ }^{13}$ Other policies in this category include the imposition of limits to the exposures of banks to real estate and equity and restrictions to the investment portfolios of domestic pension funds.

The second group, which can be identified as the "pricing-risks-right" approach to regulation works by providing financial incentives to managers and owners of financial institutions to avoid excessive risk-taking activities. The main feature of this set of regulations is that they encourage financial institutions to internalize the costs associated with the particular risks of the environment where they operate. Policies in this group include ex-ante risk-based provisioning rules and capital requirements that are designed to take into account the particular risk features of developing countries. As will be discussed below, these risk features may differ significantly from those faced by financial institutions in industrial countries. This category also includes the enforcement of market discipline mechanisms to encourage holders of financial sector liabilities to discriminate among financial institutions according to risk. By inducing financial institutions to internalize the costs of holding high-risk assets, this regulatory approach also aims at minimizing the social cost of financial sector disturbances.

Most efforts in developing countries have been concentrated on the first set of policies. This section will discuss and assess the effectiveness of two of the most common policy tools in this group, reserve or liquidity requirements and capital requirements as recommended by the Basel Committee, in controlling the adverse impact of volatile capital flows on the domestic financial systems. The next section will discuss whether the "pricing-risk-right" approach to prudential regulation can do a better job than more commonly used policies.

\section{A. Can Reserve Requirements Play an Effective Prudential Role in Dealing with Capital Flow Volatility?}

\footnotetext{
${ }^{12}$ A similar, although not exactly equal, classification of regulation is discussed in Barth et al (2001).

${ }^{13}$ As will be discussed below, capital standards designed to appropriately reflect the risk-features of bank portfolios in developing countries would belong to the category of "incentives-based" regulations.
} 
The use of reserve requirements in developing countries has evolved significantly over the last quarter of a century. As mentioned in Section II, high reserve requirements in the 1970s and 1980s were often used as a mechanism to finance fiscal deficits with banks' resources. Indeed, an important component of the first "cluster" of reforms was to reduce reserve requirements as a complement to the elimination of governments' credit controls. During the mid 1990s, after the severe banking crises that followed the exchange rate crisis in Mexico, reserve requirements, and more generally "liquidity requirements" were given a new role: this instrument could be used as a "prudential" device to limit the intermediation of large amounts of capital inflows through weak banking systems. An additional argument for high reserve requirements as a prudential regulatory tool is that they can act as a cushion to protect banks from sudden withdrawal of funds, especially in the context of a sudden reversal of capital inflows $^{14}$. By ensuring the availability of liquidity to meet unusually large withdrawals of deposits, reserve requirements may contribute to the stability of the banking system. ${ }^{15}$ This role could be particularly effective if the resources derived from the requirements are placed abroad in foreign- currency denominated assets.

This paper deals only with the role of reserve requirements in controlling the availability of liquid assets in the economy. It does not discuss the differentiation of reserve requirements on deposits denominated in domestic currency and deposits denominated in foreign currency. This distinction is fully analyzed in other papers in this volume dealing specifically with pros and cons of capital controls.

Enthusiasm for the use of reserve requirements as a prudential tool grew strong in a number of developing countries after the events in Argentina during the banking crisis that ensued in early 1995, following the Tequila crisis in Mexico. Before the crisis, during the period of large capital inflows (1991-94), the Argentinean authorities had imposed high reserve requirements. The funds generated by these requirements were invested in foreign-currency liquid assets, such as bank deposits in large banks in New York or US Treasury Bills, either by the Argentinean banks themselves or by the Central Bank. Following the uncertainties in international capital markets that resulted from the Tequila crisis, investors withdrew large amounts of deposits from Argentinean banks, especially from large banks owned by provinces and municipalities. Over 70 percent of the deposit loss was financed by a decline in liquid assets. The central bank accommodated the decline in assets by sharply reducing reserve requirements. ${ }^{16}$ Hence, it can be argued that high reserve requirements allowed a number of banks in Argentina to withstand large deposit withdrawals following an unexpected reversal of capital inflows.

What made reserve requirements serve their designed purpose in the Argentinean case? In addition to a well-managed system by the Central Bank, it is important to stress that a key reason for its success was that significant sources of liquidity in Argentina were limited to

\footnotetext{
${ }^{14}$ For an analysis of the effects of reserve requirements on real variables such as output and the real exchange rate, see Reinhart and Reinhart (1997).

${ }^{15}$ When reserve requirements are remunerated, they are usually referred to as "liquidity requirements". In addition, in a number of cases, liquidity requirements include not only funds deposited in the central bank but also liquid funds that can be managed by the banks and invested in certain category of liquid assets previously defined by the central bank.

${ }^{16}$ For further details on this episode, see Rojas-Suarez and Weisbrod (1996).
} 
practically only cash and bank deposits. ${ }^{17}$ Let me explain. The prudential role of reserve requirements to provide international liquidity to the financial system can be undermined if there are substantial amounts of short-term paper (issued either by the private sector, the government or the central bank) that are not held on the balance sheet of banks. If a sudden loss of confidence in the financial system causes investors holding this paper to attempt to flee the market at the same time as deposit-holders are withdrawing their funds, international assets generated from placing reserve requirements on bank deposits may not be enough to cover the demand for international reserves generated by the combination of the sale of government or corporate shortterm paper and the withdrawal of bank deposits. ${ }^{18}$

The discussion above indicates that for reserve requirements to be effective as a prudential regulatory tool in dealing with capital flow volatility it is necessary that: (a) bank deposits account for most liquid assets in the economy, and (b) reserve requirements be invested in liquid foreign-denominated assets. Moreover, even if conditions (a) and (b) are satisfied, banks will have an incentive to avoid the requirements if they perceive that the requirements are excessive relative to the liquidity they would hold in the absence of the regulation. A well-known mechanism to avoid reserve requirements in developing countries has been the booking of domestic business in off-shore branches. In the 1990s, this was a common practice in Colombia, Costa Rica and Malaysia. Banks can also borrow and lend short-term funds in other markets, often called mesa de dinero in Latin America, that do not appear on their balance sheets and are, therefore, not subject to reserve requirements.

Conditions (a) and (b) above provide a simple, yet meaningful way to assess the potential effectiveness of current reserve requirements in developing countries. Consider first condition (a). Since reserve requirements are part of the monetary base, countries with high reserve requirements on bank deposits should display a low ratio of liquid financial assets to monetary base, unless non-deposit securities are a substantial component of liquid assets ${ }^{19}$.

Chart 4a shows the ratio of liquid assets to monetary base against average reserve requirements for a sample of developing countries in early $2003 .^{20}$ The major finding derived from the Chart is that there is no straightforward relationship between the ratio of reserve requirements and the ratio of liquidity to base money. For example, in 2003, the ratio of liquidity to monetary base was the highest for countries with very different reserve requirements: Korea and Chile with low reserve requirements and Singapore and Brazil with very high reserve requirements. In these four countries, non-bank short-term securities,

\footnotetext{
${ }^{17}$ This changed substantially in Argentina in the late 1990s when the government' issue of domestic debt increased significantly providing an alternative source of liquidity.

${ }^{18}$ It could be argued that a flexible exchange rate system would avoid the problem of "insufficient foreign exchange reserves". However, if a sharp decline of confidence leads to a run on the financial system, a sharp depreciation of the exchange rate would have limited usefulness to contain the run as investors would be in search of foreign cash. Since a sharp depreciation of the currency cannot generate foreign funds "quickly enough", the run would not be contained.

${ }^{19}$ The sample used in Charts $4 \mathrm{a}$ and $4 \mathrm{~b}$ includes only those countries that keep traditional reserve requirements. It excludes countries that have move to the broader concept of liquidity requirements. To exemplify this, Mexico is shown as having zero reserve requirements. This country, however, maintains regulations regarding liquidity requirements.

${ }^{20}$ Data on reserve requirements for Latin America is taken from López Valdés and Jiménez (2003). The rest is taken from the web pages of the corresponding Central Banks.
} 
especially government paper, are important components of the domestic financial systems. In these countries, therefore, reserve requirements can have very limited capacity to contain the expansion of liquidity.

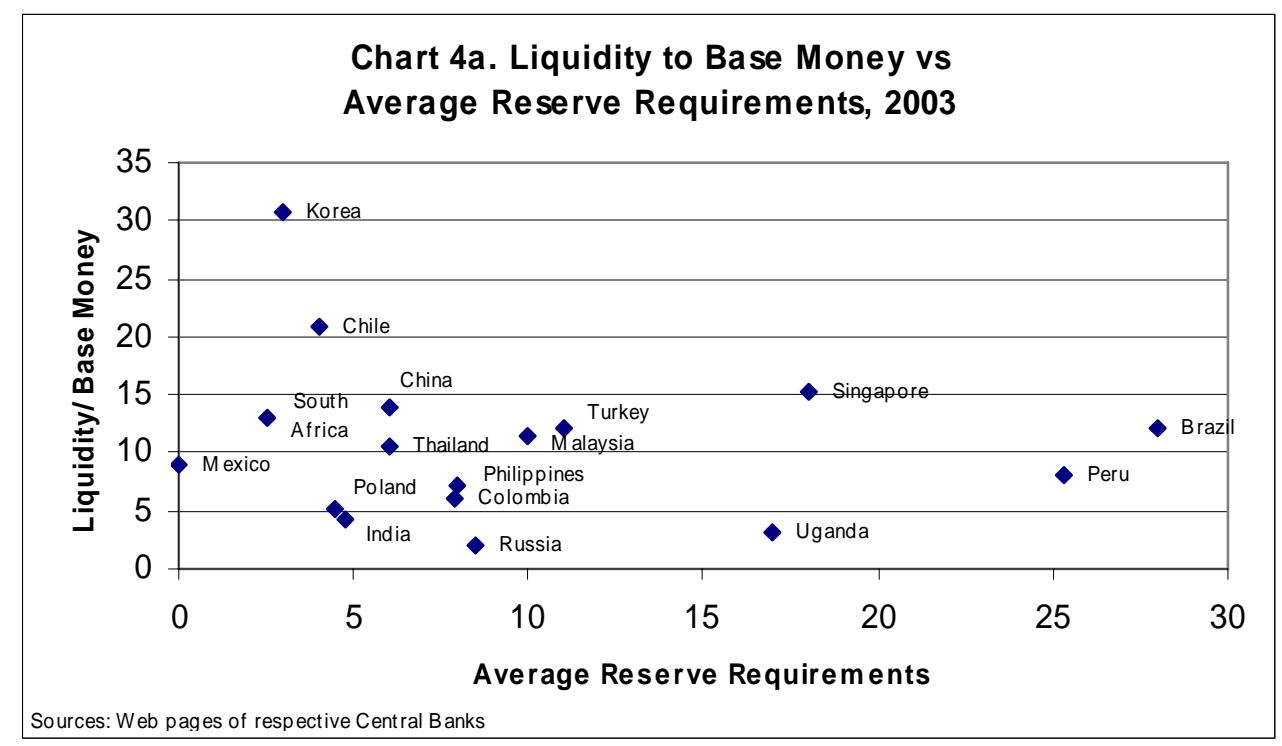

Turning to condition (b), even if bank deposits account for most liquid assets, reserve requirements can not provide protection against an unexpected reversal of capital inflow unless the funds generated by the requirements are, in fact, invested in international reserve assets. This condition is particular to developing countries and is a reflection of the high volatility of the real value of domestic financial assets discussed in Section II.

Chart 4b plots the ratio of liquidity to international reserves against reserve requirements for a sample of developing countries. As shown in the chart, taken together the countries in the sample do not display an inverse relationship between the level of reserve requirements and the ratio of liquid assets to international reserves. While Peru 


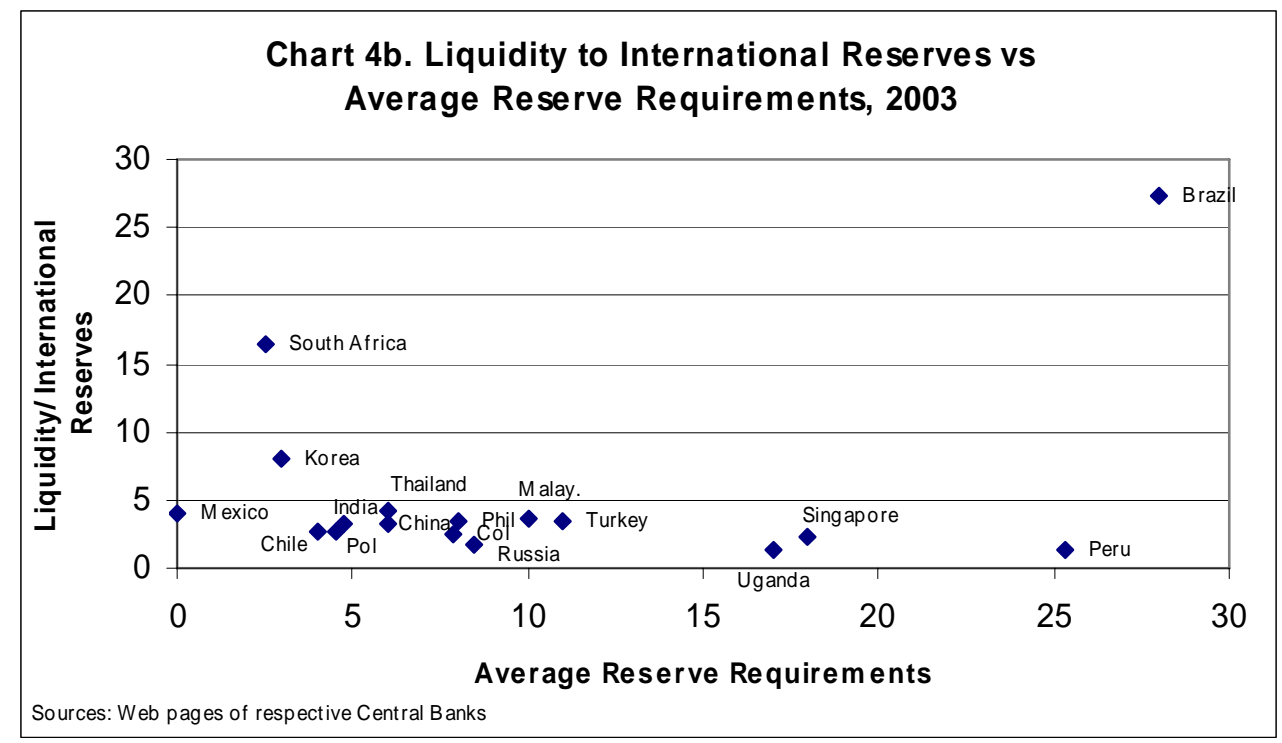

and South Africa conforms to the inverse relationship, the rest of the countries show no clear relationship between the two indicators. For example, Mexico (with zero reserve requirements) and Chile, India and Poland (with low reserve requirements) display a ratio of liquidity to international reserves similar to that of Singapore (with high reserve requirements). Moreover, Brazil, the country with the highest reserve requirements in the sample also has the highest ratio of liquidity to international reserves. This indicates that funds from the requirements have often not been invested in international reserves.

Thus, the analysis above raises caution about the effectiveness of reserve requirements as a prudential regulatory tool to face capital account volatility. While certainly there are some countries that satisfy both condition (a) and (b), these conditions seem not to be met by many developing countries.

Moreover, even if reserve requirements are effective in providing liquidity to banks when needed, this policy has an important drawback: it is applied equally to weak and strong banks. Because strong banks are better positioned than weak banks to maintain liquidity by ensuring that its borrowers remain liquid, the tax imposed by reserve requirements penalize strong banks harder than weak banks. 


\section{B. Have Capital Adequacy Ratios been Effective in Dealing with Capital Flow Volatility?}

Capital requirements are an additional prudential tool to deal with the volatility of capital flows. The aim of this policy is to contain the expansion of excessive risk-taking by banks. This is done by requiring banks to comply with a risk-weighted capital to assets ratio determined by the regulators. At least at the conceptual level, riskier assets are assigned higher capital charges.

If capital requirements were, indeed, estimated to reflect the "true" risk features of banks' portfolios and could be effectively enforced, this supervisory tool would indeed be a powerful mechanism to deal with capital flow volatility. Moreover, under those conditions capital standards would have two important advantages over reserve requirements. First, the problem of evasion inherent to a high reserve requirements policy would be avoided. Second, banks with riskier portfolios would be required to hold more capital than banks with sounder portfolios. Thus, the tool would allow supervisors to focus on weaker banks since capital ratios would decline in those banks that increase their risk-taking activities, hence providing an early-warning signal for supervisors. In a period of large capital inflows, this policy would limit the risk-taking of banks that intermediate the inflows.

Encouraged by the perceived success of capital requirements as a supervisory tool in industrial countries, developing countries were advised to adopt similar rules for capital adequacy. Consequently, during the 1990s many developing countries directed their financial reform efforts towards implementing the recommendations of the Basel Accord on capital requirements. However, albeit with quite diverse outcomes, the recent experience of banking problems in developing countries, especially in emerging markets, indicates that capital requirements as suggested by industrial country standards often have not performed their expected role as an effective supervisory tool, as the accumulation of capital in banks' balance sheets has not acted as a "buffer" to deal with unexpected adverse shocks to banks.

Recent evidence can be used to substantiate the statement above. Chart 5 shows growth rates of banking systems' net equity during the year prior to the eruption of a major banking crisis. If equity capital were at all a good indicator of banking soundness (that is, insufficient or decreasing capital should be signaling banking weakness), banks in countries about to fall into major crisis should be facing difficulties in raising capital. This has indeed been the case prior to banking crises in industrial countries. As shown in Chart 5, during the year before the eruption of banking crises in Sweden, Norway and Japan, net real equity growth became negative. In contrast, at the eve of disastrous crisis episodes in developing countries, real net equity growth was not only positive, but also reached very high levels. Cases in point are Thailand, Mexico and Ecuador, where judging from the rapid accumulation of equity capital, this indicator did not serve well as a signal for major banking turbulence.

Further evidence that capital ratios have been largely meaningless in signaling banking problems in many developing countries is contained in Rojas-Suarez (2001). The main result of that study is that, among traditional indicators used by supervisors as early warning indicators of banking problems, the capital to asset ratio has performed the worst. For example, in Mexico, a 
country that claimed to have adopted the capital standards recommendations of Basel just before the eruption of the 1994-95 banking crisis, the behavior of the risk-weighted-capital-to-asset ratio was useful in predicting problems accurately in only 7 percent of the banks that experienced severe crises. Indeed, according to the data provided by the Mexican Supervisory Authority, most banks in

Mexico were in full compliance with capital requirements and held a ratio well above 8 percent!

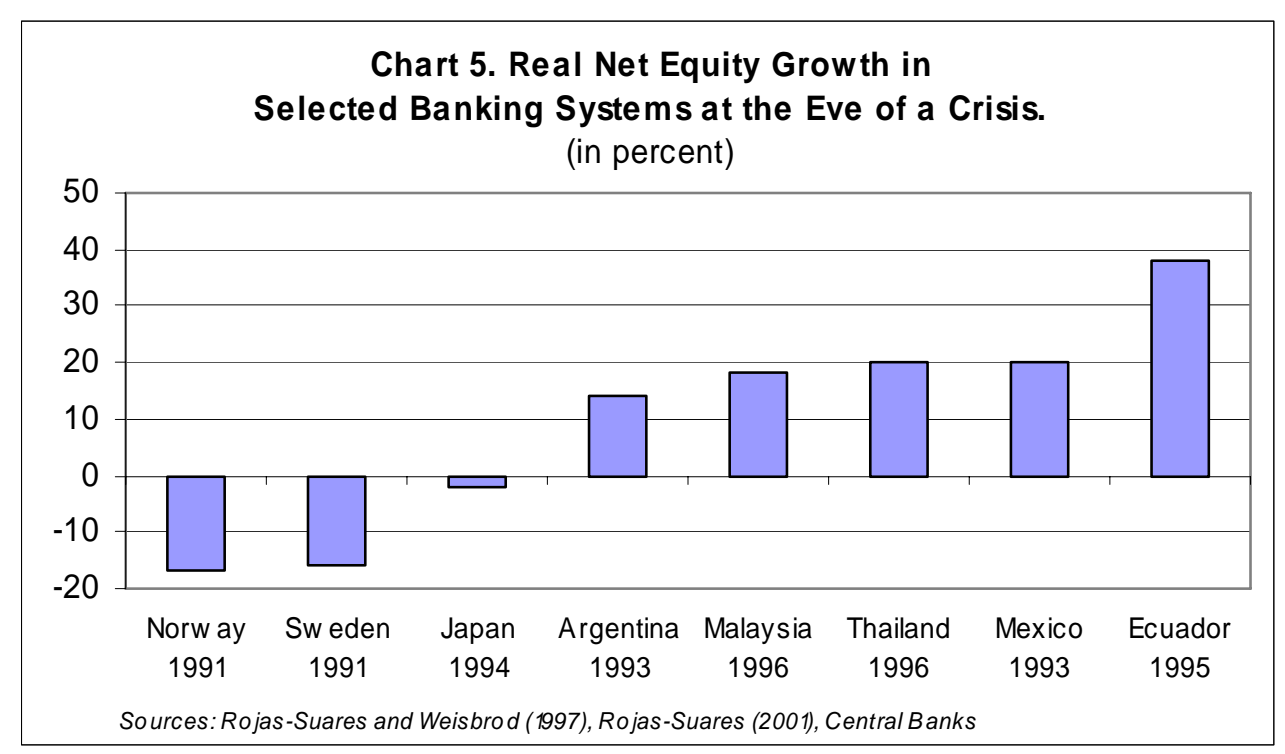

The conclusion that can be derived from the above evidence is not that capital requirements can be of no use for supervisors in developing countries ever. As the discussion below demonstrates, the conclusion is that for the capital standards to be effective the standards need to take into account the specific risk features of developing countries. Just adopting standards that are based on the risk characteristics of industrial countries simply does not work.

Why haven’t capital adequacy ratios been effective prudential tools in developing countries? The reasons for the disappointing performance of this instrument can be broadly organized into two groups. The first group relates to the specific structural features of financial markets in developing countries, including those discussed in Section II as well as those related to the concentration of ownership of financial and real assets. The second group relates to the particular characteristics of the Basle capital standard, the standard chosen by most developing countries. It is argued here and elsewhere (see Rojas-Suarez (2001)) that implementation of the specific risk weights for different categories of assets contained in the Basel capital standard might exacerbate rather than reduce the vulnerabilities of domestic financial markets to capital flow volatility.

A clarification is needed here. The discussion in the rest of this paper mostly refers to the capital standard currently used by many developing countries; namely the 1988 Accord (Basel I). In June 2004, a new Accord (Basel II was finalized by the Basel Committee on Banking Supervision for implementation beginning by the end of 2006 in some countries. While this paper does not deal with Basel II, it is important to point out that the large majority of conclusions reached here regarding the limited effectiveness of Basel I to control excessive risk- 
taking activities by banks in developing countries, remain valid under Basel II. As will be discussed below, the explanations lie not only on the specifics of the regulation, but, most importantly, on the structural features of many developing economies.

Let us now discuss the first set of reasons constraining the effectiveness of capital requirements. To determine the factors included in this first group, we raise the following question: Assuming that banks' risks were appropriately estimated in the capital standards, what features in developing countries could prevent the standards from working properly? As is well known, compliance with adequate accounting and regulatory frameworks is necessary to make the capital adequacy standard work. Inappropriate accounting standards and reporting systems and improper classification of non-performing loans stand out as the best examples of inadequacies reducing the effectiveness of capital requirements. In addition, a deficient judicial framework, that is unable to enforce supervisory actions when a bank's performance is deemed faulty, seriously undermines the efficiency of bank ratios. Indeed, in spite of advances in reforms presented in chart 1 , these factors are also behind the lack of investors' confidence in the stability of domestic financial sectors discussed in Section II.

But if these inadequacies were the only factors preventing capital standards from working, concerns about the appropriateness of the capital standard for developing countries would be exaggerated. All that would be needed is an adequate prioritization and ordering of the principles stated in the Basel's Committee's Core Principles for Effective Banking Supervision. This, in fact, is often done in practice. A more fundamental problem with the capital standards, however, goes beyond the establishment of rules and regulations into a feature particular to developing countries, namely the lack of deep and liquid capital markets. This factor implies that, even when accounting, reporting and legal frameworks are adequate, capitalization ratios will be less effective if liquid markets for bank shares, subordinated debt, and other bank liabilities and assets are not available to validate the "real" value of bank capital (as distinct from its accounting value). Therefore, since these markets are typically either not available or not liquid in developing countries, changes in the market value of bank capital that provide supervisors in industrial countries information regarding the quality of reported capital are not an effective instrument in developing countries.

In contrast to industrial countries, asset ownership, both financial and real, is still highly concentrated in many developing countries, making the potential market for equity capital small and uncompetitive. In such an environment, the intent of the capital standard - to increase the proportion of uninsured funding (equity and subordinated debt) to insured funding (deposits) in order to reduce bank stockholders' incentive to take risks at the expense of existing public safety nets--can be easily subverted. ${ }^{21}$ Shareholders' wealth may not really be at risk when they supply equity capital to a bank because shareholders can finance their stake with a loan from a related party, which could even be a non-financial corporation and hence outside the regulators' purview. Thus, concentration of wealth provides incentives for bank owners to supply lowquality bank capital and, therefore, to undertake higher risks than bank shareholders in industrial countries would allow.

${ }^{21}$ This point has been advanced by Rojas-Suarez and Weisbrod (1997); and Rojas-Suarez, L. (2001) 
This suggests that it can be relatively easy for bank owners in several developing countries to raise large amounts of low-quality equity capital relative to the bank's capital base in a short time. Indeed, this feature may explain the results shown in Chart 5: the rapid growth of net "accounting" equity displayed at the eve of banking crises in several developing countries reflects the "low quality" of capital in these economies. Lacking a market that assesses the quality of bank capital, capitalization ratios cannot serve as an effective supervisory tool.

Clearly, the severity of this problem varies widely across developing countries. For many countries, the constraints limiting the usefulness of capital requirements are extremely binding, and therefore beg the question: Is there an alternative to the use of capital standards for assessing the strengths of banks now, in the immediate future, when preconditions for the effectiveness of the capital standard are not in place? These questions will be dealt with Section IV.

In some other countries, however, a continuous increase in the participation of foreign banks from industrial countries (as shown in Chart 2) is de facto reducing the degree of connected lending among financial institutions and between financial institutions and the real sector. Furthermore, in this (still small) group of countries, the accounting, regulatory and supervisory frameworks have improved drastically. Although there are very few developing countries with sufficiently deep and liquid capital markets, ${ }^{22}$ the participation of foreign banks can provide an outside and independent source of capital in the pursuit of new wealth. The competition induced by the entry of new providers of wealth can indeed contribute to improving the usefulness of capitalization ratios.

For this group of countries, the relevant question becomes whether adopting the internationally accepted capital standards recommended by the Basel Committee is appropriate (both the current Accord and the newly published Basel II). Indeed, to determine the second group of factors explaining the observed inefficacies of capital requirements, we ask the following question: Assuming that developing countries are structurally and institutionally "ready" to effectively implement capital standards, are the Basel Committee's standards adequate for developing countries? To answer this question we first assess whether the classification of assets according to risk in the current Basel Accord "matches" risk features of bank assets in developing countries. Then, we quickly question whether a move towards Basel II could be the solution.

The contention advanced in this paper and in Rojas-Suarez (2001) is that there is a poor matching between the assessments of risks contained in the current Accord recommendations and the actual risks in developing countries. Indeed, I argue that a straightforward application of the Basel I standard can actually weaken banking systems in developing markets as the standards create incentives for banks to increase the risk characteristics of their portfolios. I will now discuss two features of the standards that have contributed to weaken rather than strengthen banks' balance sheets: the treatment of government claims held by banks and the treatment of inter-bank lending.

\footnotetext{
${ }^{22}$ Chile, Hong Kong and Singapore may be the countries, among emerging markets, with the deepest financial sectors.
} 
Regarding the treatment of bank credit to the government, under the current Basel Accord, loans to the public sector carry a $0 \%$ risk weight if the country belongs to the OECD and $100 \%$ if the loan is to a non-OECD government. The idea, of course, is that claims on OECD governments can be considered "safe assets". However, when applying the Basel recommendations to their domestic economies, most non-OECD countries attach a $0 \%$ risk weight to their own government paper. That is, banks in developing countries treat paper issued by their own governments as a "safe asset", an assumption far from reality if one takes into account the default history of emerging market governments, highlighted by the recent defaults of Argentina, Russia and Ecuador ${ }^{23}$. The problem with this practice is that by economizing on capital requirements, banks have a strong incentive to concentrate a significant portion of their asset holdings in government paper. This incentive not only gives a false impression of "bank safety," but even more importantly, also contributes to weaken the "franchise value of banks," which is rooted in their capacity to assess credit risk.

While a thorough understanding of banks' decisions to hold public vs private assets would require the specification of a complete model, it is fair to argue that the regulatory treatment of government paper has played an important role in banks' decisions. Indeed, the increase of government paper as a share of total bank assets in many countries since the mid1990s, as depicted in Chart 3, coincides with the adoption of the Basel capital adequacy recommendations in developing countries. This regulatory incentive also has important consequences during recessions as banks tend to magnify the downward trend in economic activity by shifting their portfolio further away from credit to the private sector and towards government paper as they seek to reduce capital costs.

The evidence above suggests that the regulatory treatment of banks' claims on government tends to reduce the soundness of banking systems in developing countries. ${ }^{24}$ This concern, as obvious as it may look, is, however, not taken into account when International Financial Institutions (IFIs) assess country progress in strengthening financial systems. Indeed, developing countries attaching zero risk weight to domestic government liabilities will not receive a "warning signal" from IFIs even if the government is highly indebted as such a practice is not perceived as conflicting with the international standards!

Regarding the treatment of inter-bank lending, the Basel Accord attach a risk-weight of 100 percent to bank lending to non-OECD banks with a maturity of over a year, while lending to these group of banks with a maturity of a year or less carry a risk weight of only 20 percent. The obvious result has been a bias towards short-term cross-border lending towards developing countries banks. This, of course, exacerbates the volatility of flows to developing countries as any adverse news from developing countries quickly translates in a sharp reduction of crossborder lending. $^{25} 26$

\footnotetext{
${ }^{23}$ Argentina does not attach zero risk weight to government paper, but the risk weights still favor this kind of instrument.

${ }^{24}$ A counter case may be made by arguing that domestic government debt is safer than public external debt. However, given the long history of government-induced domestic defaults, either in the form of straight confiscation of deposits or sharp devaluations and inflations that drastically reduced the real value of government paper held by residents, I find this argument simply unconvincing.

${ }^{25}$ This effect has also been discussed in Reisen (2001) and Griffith-Jones and Spratt (2001).
} 
But problems for developing countries associated with the Basel Accord treatment of inter-bank lending go beyond increased volatility of capital flows as this regulatory provision also creates incentives to decrease the maturity of loans extended by domestic banks to the local economy. The reason is that in their efforts to strengthen their banking systems, a number of developing countries have introduced regulations that reduce the maturity mismatch between banks' assets and liabilities. The shorter the maturity of international loans to banks in developing countries, the shorter the marginal maturity of loans extended by banks in developing countries to their local customers in order to prevent a maturity mismatch between banks' assets and liabilities. This, of course, adversely affects the vulnerability of economic activity to sources of funding.

Thus, a lesson from capital standards as a prudential tool to deal with capital flow volatility is that even if adequate accounting, supervisory and judicial frameworks are in place, the current Basel Accord is not the appropriate capital standard for developing countries. One of its major shortcomings is that by incorrectly assessing the risk features of developing countries, it creates incentives for excessive risk taking by banks in these countries.

Would implementation of Basel II help solve the problems outlined above? The "spirit of the recommendations", namely, an attempt to align "regulatory" capital with the "true" risk of banks portfolios, would help, but not the actual prescriptions. It would take an entire paper to explain the statement I just made. For the purpose of this document, however, it is sufficient to point out that the only approach within Basel II that allows for an adequate measurement of risk is the “advanced internal rating-based approach” (the IRB approach). The problem, however, is that the large majority of banks and supervisors in developing countries are simply not ready to implement this approach. Unfortunately, the other two approaches available under Basel II for calculating minimum capital requirements create a whole set of new problems that would have undesirable consequences for the stability of the financial systems of developing countries. See Rojas-Suarez (2001) for a comprehensive discussion of these issues. ${ }^{27}$

\section{Prudential Regulations that Work in Developing Countries: How Should They Differ from Policies in Industrial Countries?}

\section{A. The degree of Financial Development Matters a Lot}

The discussion above leads to two central conclusions. The first is that, very often, the implementation of traditional prudential regulations to deal with capital account volatility in

\footnotetext{
${ }^{26}$ The new Basel Accord aggravates this problem as the definition of short-term has been reduced from "one year maximum" to "three months maximum”. Further discussion of the problems for Latin American countries associated with the plausible implementation of the Basel II Accord is contained in Latin American Shadow Financial Regulatory Committee (2001).

${ }^{27}$ For example, a major issue in the so-called "standardized Approach” relates to the reliance on credit rating agencies for the determination of "risk weights" attached to loans in the calculation of minimum capital requirements.
} 
developing countries has not delivered the desired results. The second is that the identification of factors explaining inadequacies in prudential regulation constitutes a major step forward for improving the design of policies so that they work in developing countries.

With respect to necessary conditions for prudential regulations to work, section III showed the importance of the degree of financial development. For example, in industrial countries, where deep and liquid capital markets validate the value of accounting capital, capital ratios have proven useful. It is interesting to note that in those industrial countries with well-developed short-term non-deposits liquid instruments, such as the United States, reserve requirements have lost their effectiveness to a large extent, and are little utilized. Thus, the development of liquid capital markets tends to increase the effectiveness of capital ratios and simultaneously decrease that of reserve requirements.

In contrast, for the least developed countries in the world, wealth concentration and the resulting absence of competitive capital markets severely hinders the usefulness of any bank capital standard, not only the ones recommended by the Basel Committee. In this group of countries, reserve requirements could be potentially effective in dealing with capital account volatility. Unfortunately, inadequacies in reporting and supervisory systems are also the worst in this group of countries and these deficiencies provide fertile ground for evasion of reserve requirements.

In between these two extremes, the industrial countries and the least developed countries, there is a group of developing countries, where the participation of foreign banks has improved the functioning of the markets. Moreover, the accounting, reporting and supervisory frameworks have improved significantly. In these countries, mostly classified as emerging markets, some form of capital adequacy requirements could be an effective supervisory tool. But as Section III has argued, outright application of the Basel Accord (I or II) is not the right path to follow for strengthening their banking systems.

\section{B. Prudential Policies that Work in Developing countries}

In light of the experience discussed in section III, this section advances arguments supporting the need to develop regulatory and supervisory frameworks that better fit developing country needs. Because of the difficulties in obtaining desirable results from traditional regulatory policies, it is argued that policies that attempt to " price developing countries' risk right" may prove quite beneficial for strengthening financial sectors in these countries. As discussed above, the "pricing-risk-right" approach to regulation works by taking the particular financial features of countries into account in order to provide incentives for avoiding excessive risk-taking activities by financial institutions. In the case of industrial countries, the new Basel II proposal is based on this philosophy. The issue for developing countries is the identification of policies that would be able to provide the right incentives.

Because the degree of development matters, policy recommendations for the least developed countries need to differ from the most financially advanced developing countries. Based on a simple classification of countries into two groups according to their degree of 
financial development, the "pricing-risk-right" approach suggests that the following policy recommendations might be effective. The set of recommendations that follows is by not means complete or fully inclusive. They are simply examples of policies that are consistent with the objective of making prudential regulatory tools work.

For the first group, the financially least developed group, where traditional regulations, such as reserve requirements and any capital standards are largely ineffective, it is obvious that sustainable policies consist in removing the constraints to the effectiveness of prudential regulations. That is: (a) the implementation of appropriate accounting, reporting and judicial frameworks, that would prevent the evasion of reserve requirements and (b) the development of markets that validate the accounting capital ratios.

Those policy reforms, however, often take a significant amount of time to implement. ${ }^{28}$ In the transition to a more comprehensive reform, the "pricing-risk-right approach" suggests that it is still possible to identify and develop some indicators of banking problems that help to reveal the true riskiness of banks. For example, deposit markets have often been identified as markets that work in many developing countries in the sense that they have been able to provide effective early-warning signals about the relative strength of banks (See Rojas-Suarez 2001). Recommendations for policymakers in this set of countries, therefore, should focus on strengthening the role of market discipline. In other words, regulators should focus on developing tools that utilize information from markets that already work or that can be developed in a relatively short period of time. The central idea is that, if encouraged to do so, depositors and other holders of banks' liabilities can discriminate between sound and weak banks by "pricing risks" adequately by, for example, charging higher interest rates on deposits or withdrawing deposits from financial institution perceived to be unsound.

The key for market discipline to work, however, is the elimination of distortions that encourage bank liability holders not to discriminate among banks. A typical example that "kills" market discipline is a deposit insurance scheme that promises unlimited coverage to all depositors. It is important to stress that, as long as the institutions determining the effectiveness of prudential regulation remain weak, market discipline cannot work at its best. The recommendations that follow, therefore, can ease but not solve the problems associated with an inadequate regulatory framework.

With this in mind, specific recommendations that promote market discipline include: (a) encourage the public offering of uninsured certificates of deposits; (b) publish inter-bank bid and offer rates to improve the flow of information on bank quality; (c) develop "credit bureaus" that provide timely and relevant information about debtors creditworthiness; (d) encourage the process of financial internationalization--through promotion of foreign banking - as adequate market depth can only be achieved if a diverse group of investors and users of capital enter the market; that is, if the market becomes less concentrated; (e) strengthen regulatory efforts on improving deposit insurance schemes to credibly limit the insurance while ensuring that the scheme is sufficiently funded to finance the closing or selling of financial institutions in severe

\footnotetext{
${ }^{28}$ Moreover, reducing concentration of financial and real assets could be a difficult task especially in countries where some political powers are "captive" to the agenda of economically powerful groups.
} 
difficulties; and (f) avoid excessive bank access to central bank liquidity to contain moral hazard problems associated with the existence of a lender of last resort;

The last two recommendations (avoid generous deposit insurance and excessive access to central bank liquidity) can be credibly implemented in cases where "contagion" within the domestic financial system is limited. Very often, however, the failure of a large bank creates systemic problems that have led authorities to intervene in order to prevent the eruption of a major crisis. The policy recommendation from recognizing the existence of contagion is twofold. First, in order to avoid the eruption of systemic problems, improve the credibility of the safety net by establishing "prompt corrective actions" to minimize the expansion of incipient banking problems. Second, if in spite of preventive efforts, a systemic crisis nevertheless materializes, recognize that the solution of the problem should involve: (a) keeping the payments system alive, and (b) minimize the fiscal cost of banking crisis resolution. ${ }^{29}$

Policy recommendation are quite different for the second group of developing countries, namely those with a sufficient degree of financial development to allow traditional prudential regulatory policies to be meaningful, but where their particular features such as limited access to international capital markets imply that strict application of industrial-country regulation, such as the Basel Accord, may be of limited effectiveness. In this group of countries, the recommendations advanced for less financially developed countries have to a large extent already been implemented.

Following the "pricing-risk-right" approach, reserve requirements does not seem to be a desirable tool not only because it loses it effectiveness as alternative sources of liquidity develop in the domestic markets, but also because it does not discriminate between different levels of bank quality. These arguments may explain Mexico's decision to eliminate reserve requirements and the low ratios currently observed in Chile.

Instead, the main recommendation for this group of countries is to design a transitional capital standard that appropriately reflects the risk of banks' assets because Basel (I or II) does not fit the bill in the short-run. This paper recommends that the standard should have two basic components. The first is the development of ex-ante risk-based regulations in loan-loss provisions. While this is widely recognized by the Basel Committee to be an essential complement to any capital standard, the proposal in this paper is one based on prioritization. Given the high frequency of adverse shocks in developing countries, especially the sudden reversal of capital inflows, the expected probability of occurrence of these adverse outcomes is very high compared to industrial countries. In this environment, provisioning takes a role, at times, more important than capitalization. Ex-ante risk-based provisioning would be a significant departure from current practices in almost all developing countries ${ }^{30} 31$

The second characteristic is the establishment of a reduced number of risk categories to classify assets, with the central qualification that the categories of risk should reflect the

\footnotetext{
${ }^{29}$ See Rojas-Suarez (2004).

${ }^{30}$ This point has been raised by Cavallo and Majnoni (2001)

${ }^{31}$ The use of ex-ante provisioning as an effective counter-cyclical prudential regulation tool is discussed in Ocampo (2003).
} 
particular features of banks' assets in developing countries. If loan-loss reserves are designed to reflect the expected losses in banks' assets, minimum capital requirements need to reflect unexpected losses. Issues that need to be considered in the design of appropriate risk categories include an adequate risk assessment of government paper and the introduction of distinct capital charges for borrowers in the tradable and non-tradable sectors. ${ }^{32}$

The problems associated with attaching risk weights to government paper that severely understates the risk features of those assets have already been discussed throughout the paper. It is, however, important to stress that as long as governments do not make the political decision to correctly price the risk of their own liabilities, banks will have an incentive to discriminate against credit to the private sector relative to the public sector. Moreover, this inadequacy has an important adverse consequence for the effects of the volatility of capital flows: At times of increased uncertainties in the international capital markets, governments will have an incentive to turn to their domestic banking sector to place additional debt. While this will have the shortterm advantage of allowing governments to continue their fiscal plans, the policy increases the risk features of domestic bank portfolios and prevents market signals originating in the capital markets from inducing governments to undertake necessary fiscal adjustments. The recent crisis in Argentina is an excellent example of how banking systems can be weakened by the incorrect pricing of risk of government paper. While in the mid-1990s, the ratio of government paper held by banks was about 15 percent, this ratio had escalated to over 30 percent by 2001. Not surprisingly, the international debt crisis at the end of 2001 also translated in a severe banking crisis. $^{33}$

The need to distinguish risk features between tradable and non-tradable sectors when calculating capital requirement responds to the well-known fragility of the latter sector to adverse unexpected shocks, such as a sudden stop of international capital inflows. In developing countries, market risks - especially exchange rate risk — quickly translates into credit risk, especially for the non-tradable sector. While the need to distinguish risk characteristics between sectors can certainly help to strengthen domestic banking systems, the issues involved with this policy are quite complicated and cannot be resolved in this paper. The problem is that "pricing risk right" in this context could bring about a reduction in bank credit to small enterprises or to producers in the agriculture sector, from already depressed levels. Thus, the social problems created from this policy could be larger than its potential contribution to the stability of the financial system. The only conclusion that I will derive here is that the risk features of different sectors should not be ignored when designing capital standards, but that additional and complementary policies would need to be in place to prevent the elimination of sources of funding to enterprises in the non-tradable sector.

Additional recommendations to allow these countries to deepen their financial systems and, hence, improve the effectiveness of accepted international prudential regulation include: (a) further enhancing the mechanisms of market discipline beyond the recommendations advanced

\footnotetext{
${ }^{32}$ For a more comprehensive analysis of this proposal, see Rojas-Suarez (November, 2001).

${ }^{33}$ Some analysts have argued that the interference of the government in Argentina's banking system, including the freezing of deposits, was the cause of the crises. Those measures, however, might have not been considered if bank assets were strong. With one third of banks' asset invested in government paper of little value, the banks were in severe problems even if additional measures had not been taken.
} 
for the least developed group of countries. An example is the use of the information in credit bureaus to estimate the probability distribution of loan losses an, therefore, to calculate adequate requirements for capital and provisioning (See Powell 2001); and (b) deepening the process of financial internationalization through the increased participation of foreign institutional investors, especially pension funds and insurance companies.

\section{Concluding Remarks}

This paper has shown that traditional prudential regulatory policies used in industrial countries have had limited effectiveness in controlling the adverse impacts of capital account volatility on financial systems in developing countries. The main reason for this disappointing result is that, by not taking into account the particular characteristics of financial markets in developing countries, these regulations cannot effectively control excessive risk taking by financial institutions. Moreover, the paper shows that contrary to policy intentions, some of these regulations, such as the Basel Accord on capital requirements, can exacerbate rather than decrease financial sector fragility, especially in episodes of sudden reversal of capital flows.

Important features that distinguish financial markets in developing countries from those in industrial countries include the predominance of assets with short maturity and high volatility as well as the large concentration of financial and real assets. These features significantly decrease the effectiveness of traditional prudential regulatory instruments. For example, reserve requirements cannot be effective in developing countries with abundance of short-term government paper because, in a highly volatile environment, holders of these instruments would tend to flee the markets at the same time as depositors are withdrawing their funds, rendering insufficient the amount of foreign exchange reserves--generated from placing reserve requirements on deposits--to meet the demand for foreign currency.

Likewise, because assets in developing countries have different risk characteristics than assets in industrial countries, there is a poor matching between the assessments of risks contained in the current Basel recommendations implemented in developing countries and the actual risks faced by banks in these countries. This implies that a straightforward application of Basel I can actually weaken banking systems in developing markets as the standards create incentives for banks to increase the risk characteristics of their portfolios. The paper also points out that the implementation of the new Accord for minimum capital requirements (Basel II) is not the solution for developing countries at least in the short and medium-term. The "advanced" approach for the calculation of capital requirements is simply "out of limits" for developing countries. Ironically, the method that could be implemented by a number of developing countries, the "standardized approach" would open up a whole new set of problems with adverse consequences for the stability of developing countries financial systems.

The paper argues that the shortcomings of traditional prudential regulations can be overcome to a significant extent by following a "pricing risks right" approach to regulation, whose main feature is to encourage financial institutions to internalize the costs associated with the particular risks of the environment where they operate. In doing so, the approach attempts to provide incentives to avoid excessive risk-taking by financial institutions. 
The "pricing risk right" approach recognizes that developing countries are not a uniform group of countries and that, therefore, regulatory policy should not be uniformly implemented in all countries. The claim is that the degree of financial development matters and that policies should be implemented taking those differences into account.

By using a simple division of developing countries in two groups, the paper advances policy recommendations that are consistent with the "pricing risks right" approach. For the least developed group of countries, where concentration of financial and real assets is high and where basic accounting and judicial standards are inappropriate, the challenge is to identify and develop indicators of banking problems that reveal the true riskiness of banks. These indicators can be found, at least partially, in markets that already work such as the deposit markets. Specifically, recommendations for policymakers in this group of countries focus on strengthening the role of market discipline, while working on removing the inadequacies of traditional prudential regulations. Some of the recommendations include: encouraging the public offering of uninsured certificates of deposits and publishing inter-bank bid and offer rates to improve the flow of information of bank quality. Equally important is the need to encourage the process of financial internationalization as market depth can only be achieved if a diverse group of investors and users of capital allow the market to become less concentrated.

For the second group of developing countries, the relatively more financially developed, the main recommendation is to design a capital standard that appropriately reflects the risk of banks' assets because Basel (I or II) does not fit the bill--at least in the immediate future. Among the policy recommendations advanced in this paper, there are two that stand out for their importance. The first is for governments to adequately assess the risk features of their own liabilities when calculating capital requirements. Not doing so increases the vulnerability of banks to shocks in the international capital markets and induces banks to crowd out loans to the private sector in favor of the government. The second crucial recommendation is the development of risk-based regulations in loan-loss provisioning. This would be a major deviation from current practices in the large majority of developing countries.

In sum, traditional prudential regulatory policies cannot effectively contain the problems associated with capital flow volatility because they do not take adequate consideration of the particular risk features of financial sectors in developing countries. Hopefully, the day will come when the financial development gap among countries will be significantly reduced permitting the convergence of regulations throughout the world and, therefore, eliminating concerns about regulatory arbitrage. In the meantime, however, implementing policies that create incentives for financial institutions in developing countries to "price right" the risks inherent to the assets they hold might go a long way to mitigate the adverse effects from capital account volatility. 


\section{References}

Abiad, Abdul and Ashoka Mody, "Financial Reform: What Shakes It? What Shapes It?, International Monetary Fund, Working Paper N0. 03/70, Washington D.C. April 2003.

Barth, James, Gerard Caprio Jr. and Ross Levine, “The regulation and Supervision of Banks Around the World: A New Database”, in Robert E. Litan and Richard Herring (eds.), Integrating Emerging Market Countries into the Global Financial System, Brookings-Wharton Papers on Financial Services, Brooking Institution Press, (2001)

Barth, James, Gerard Caprio Jr. and Ross Levine, "Bank Regulation and Supervision: What Works Best? World Bank Working Paper, August 2001.

Cavallo, Michele and Giovanni Majnoni, “Do Banks Provision for Bad Loans in Good Times” Empirical Evidence and Policy Implications, World Bank, June 2001.

Díaz-Alejandro, Carlos, “Good-Bye Financial Repression, Hello Financial Crash”, Journal of Development Economics, vol. 19, September/October 1985.

Griffith-Jones, Stephanie and S. Spratt, "Will the Proposed New Basel Capital Accord have a Net Negative Effect on Developing Countries”? mimeo, Institute of Development Studies, University of Sussex, 2001

Latin American Shadow Financial Regulatory Committee, “The New Basel Capital Accord and Financial Stability in Latin America”, Statement No. 2, Caracas, April 2001.

Latin American Shadow Financial Regulatory Committee, "Foreign banks: Do they Strengthen the Financial Systems of Latin America?“ Statement No. 7, Lima, November 2002.

Lopez Valdes, Jose Manuel and Francisco Jimenez, “ La Regulación Bancaria en América Latina”, Asociación de Bancos Comerciales de la República Dominicana, 2002.

Powell, Andrew, “A Capital Accord for Emerging Economies”?, mimeo, Universidad Torcuato Di Tella, September 2001.

Ocampo, Jose Antonio, “Capital Account and Counter-Cyclical Prudential Regulations in Developing Countries” in Ricardo Ffrench-Davis and Stephany Griffith-Jones (eds.), From Capital Surges to Drought: Seeking Stability for Emerging Markets, Palgrave/Mac Millan, London 2003

Reinhart, Carmen and Vincent Reinhart, "On the Use of Reserve Requirements in Dealing with Capital Flows Problems”, The International Journal of Finance and Economics, Vol. 4, No. 1, pp. 17-54, January 1999 
Reisen, Helmut, "Will Basel II Contribute to Convergence in International Capital Flows?” mimeo, OECD Development Center, May 2001.

Rojas-Suarez, Liliana, “Argentina and Uruguay: Two Contrasting Experiences of Banking Crisis Resolution” Federal Reserve Bank of Chicago, forthcoming 2004.

Rojas-Suarez, "International Standards for Strengthening Financial Systems: Can Regional Development Banks Address Developing Countries Concerns" In Nancy Birdsall and Liliana Rojas-Suarez (eds.), Financing Development: The Power of Regionalism, Center for Global Development, 2004.

Rojas-Suarez, Liliana, "Banking Crises in Latin America: Can Recurrence be Prevented?, paper presented for a World Bank Conference on Banking Supervision, Montevideo, March 2002.

Rojas-Suarez, Liliana, "Can International Capital Standards Strengthen Banks in Emerging Markets”?, The Capco Institute Journal, $5^{\text {th }}$ edition, 2002. Also in Institute for International Economics, Working Paper WP01-10, Washington D.C. November 2001

Rojas-Suarez, Liliana and Steven Weisbrod, "Building Stability in Latin American Financial Markets” Inter-American Development Bank, Working paper series No. 320, Washington D.C., February 1996 